\title{
The Isolation in Eggs of a New Filtrable Agent which may be the cause of Bovine Lumpy Skin Disease
}

\author{
By M. van den ENDE, PHYLlis A. DON and A. KIPPS \\ The Department of Pathology, University of Cape Town
}

SUMMARY: Using a filtrate from an emulsion of skin nodules, lymph node and a milk-duct nodule from a calf dead of bovine Lumpy Skin Disease as starting material, a filtrable agent was isolated by serial passage in chick embryos. The agent affects mainly the skin structures of the chick embryo and results in a characteristic shrunken featherless embryo tightly wrapped in its amnion, and with almost complete disappearance of amniotic fluid.

The agent appears to be a filtrable virus approximately $10-25 \mathrm{~m} \mu$ in diameter. It was not pathogenic for day-old chicks and adult fowls.

The virus was neutralized by the serum of fowls which had received repeated intramuscular injections of the virus, suggesting that the virus is etiologically related to Lumpy Skin Disease in cattle. Further work is needed before such a relationship can be regarded as established.

The virus withstood heating to $60^{\circ}$ for $20 \mathrm{~min}$., survived in $50 \%$ glycerol for at least 1 week, and at a temperature of $+4^{\circ}$ for at least a month. It was destroyed by boiling for $2 \mathrm{~min}$. and by incubation at $37^{\circ}$ overnight. Desiccation destroyed a large part of the virus in a suspension, but that part which withstood the drying process survived for at least a month.

Towards the end of 1946 'Lumpy Skin Disease' in cattle became a serious problem to dairy farmers in the Western Cape Province, Union of South Africa. The disease had been recognized previously and has been referred to as pseudo-urticaria (MacDonald, 1931). It is a condition characterized by transient fever, nodular lesions in the skin and lymphadenopathy, which go on to necrosis. The necrotic areas in the skin separate, leaving superficial ulcers. which ultimately heal. The mortality is low and results usually from secondary infections such as pneumonia. Animals do, however, suffer severely in general condition and milk yields are reduced. A summary of the present knowledge of the disease has been published by de Boom (1947), and the clinical picture described by Thomas \& Mare (1945) and von Backstrom (1945).

Experimental work on this disease has been carried out at The Veterinary Research Institute, Onderstepoort. On the basis of the results, the histological appearances of the lesions and the epidemiology of the disease, it was suggested that the etiological agent was probably a filtrable virus. The virus had, however, not been isolated, and transmission experiments succeeded only in bovines (Thomas \& Mare, 1945). By its high incidence in dairy herds in the Cape Peninsula the disease soon threatened to create serious economic and nutritional problems, and prompted us to undertake the investigation recorded in this paper.

\section{Material}

It was anticipated that if the disease were caused by a virus, the infective agent would be found in highest concentration in the lesions present during the early stages of the disease. A striking early manifestation was marked 
enlargement of superficial lymph nodes such as the prescapular, and lymphoid material excised during life or at autopsy was consequently used. Skin nodules which, when possible, were excised during the first few days of the disease and before the onset of gross necrosis, were also used. Not only did we anticipate a higher virus content of such early skin nodules, but the chances of secondary infection were minimized by the use of nodules with unbroken overlying epithelium.

The first attempt to isolate the virus was made with a skin nodule excised under local anaesthesia from the flank of a Jersey heifer on the second day after appearance of cutaneous nodules (series L). A second attempt was made from skin, lymph node and a mammary duct nodule from a Jersey calf which died during the first week of a severe attack of Lumpy Skin Disease. At autopsy this calf was found to have suffered also from redwater fever, which probably contributed to its death (series W). Subsequently two more attempts were made to isolate the agent from lymph nodes, excised during the early stages of the disease, and three other attempts were made with excised skin nodules as starting material.

A virus was isolated only in one series (W), reported in detail below. With the possible exception of series $\mathbf{L}$ all other attempts were negative in spite of two to five serial egg passages. Some of these were abandoned because of contamination. No significant lesions were encountered apart from an occasional gelatinous oedema of the chorio-allantois.

\section{Methods}

The nodules were excised together with an adequate rim of normal skin. The excised skin was pinned out, the hair and superficial layers of epidermis removed with a sharp razor, and the nodules thoroughly cleaned with a swab soaked in ether. The actual nodules in the skin were then excised, minced with sterile scissors, ground up as efficiently as possible in a mortar with an excess of Pyrex glass powder, and emulsified in Hartley's broth.

Such crude emulsions were of course heavily contaminated with a variety of organisms. Before inoculation into eggs they were therefore either filtered through gradocol membranes with an average pore diameter (A.P.D.) of 600-1000 $\mathrm{m} \mu$ or treated with penicillin. On several occasions, including series $W$ in which a virus was isolated, streptomycin was also added.

The emulsions were used for the inoculation of rabbits by the intradermal route and of chick embryos. On two occasions mice, gerbilles and guinea-pigs were used in addition, a variety of inoculation routes (intradermal, intraperitoneal and intranasal) being employed. Serial transfers were carried out only in eggs, usually at 3-6 days' intervals. The results obtained with laboratory rodents were uniformly negative, and these animal experiments will not be described further. Negative results with the usual laboratory animals have been reported also by the workers at Onderstepoort (cf. de Boom, 1947).

Eggs incubated for 9-14 days at $39^{\circ}$ were inoculated with approximately $0.25 \mathrm{ml}$., half being injected into the amniotic cavity and the remainder placed on the chorio-allantoic membrane. The inoculation technique employed was 
that described by Beveridge $\&$ Burnet (1946). In some cases chorio-allantoic membrane alone emulsified in Hartley's broth was used for serial transfer. In the majority of cases, however, chorio-allantois, amnion and the whole embryo except eyes, legs and wings, emulsified in approximately $15 \mathrm{ml}$. of embryonic fluids and broth, was used. In filtration experiments embryo emulsions received preliminary clarification through paper-pulp, after which they were passed through a series of gradocol membranes with A.P.D.'s varying from 1000 to $21 \mathrm{~m} \mu$.

\section{RESUL'TS}

\section{Isolation of a virus}

Series $L$. A cutaneous nodule obtained by biopsy during the second day of skin manifestation was emulsified in broth with added penicillin, and the material inoculated into four 10-day-old eggs. Two eggs opened on the 4th day after inoculation had oedematous semi-opaque chorio-allantoic membranes. One showed in addition an amniotic sac so empty of fluid that the amnion was closely applied to the embryo. Another opened on the 5 th day showed a number (c. 30) of indistinct small focal lesions in the chorio-allantois.

From the first two chorio-allantoic membranes and succeeding ones a number of serial transfers were made in eggs. Most of the eggs used for these passages were 12-14 days old before inoculation. One such series went to the 7 th passage, others were discontinued after 3rd, 4th or 5th passage. Attention was paid almost entirely to the focal lesions on the chorio-allantois. They occurred, however, with great irregularity, and with continued passage became increasingly difficult to identify even with the aid of a hand lens. Although this attempt to isolate a virus was finally abandoned, several observations were made which are worth recording in the light of subsequent observations.

Thus a very marked gelatinous oedema, especially of the chorio-allantois but occasionally also of the embryo itself, was noted repeatedly. In one of the eggs, which received the original skin emulsion, the amnion was tightly applied to the shrivelled embryo-an appearance recognized as significant in the next series (W); and in an egg of 5th serial passage the embryo showed abnormal feather development, with haemorrhage in the feather follicles and feather shafts.

Series $W$. The starting material consisted of an emulsion of skin nodules, lymph node and a milk-duct nodule from a calf examined within an hour of death from Lumpy Skin Disease and redwater fever. Part of the emulsion was treated with penicillin and streptomycin and the remainder was filtered through a gradocol membrane with an A.P.D. of $600 \mathrm{~m} \mu$. The material received no preliminary clarification other than an hour's centrifugation at $c .3000$ r.p.m. in a horizontal centrifuge. A second group of eggs received the penicillin- and streptomycin-treated emulsion without preliminary filtration. This material was discarded after three serial passages because of gross contamination. All these eggs and those used for subsequent transfers had been pre-incubated for 9-11 days before inoculation.

Four of the six eggs which received the filtered material were dead on or 
before the sixth day after inoculation. One of the survivors opened on the sixth day showed marked gelatinous oedema of the chorio-allantois and numerous haemorrhages into the feather follicles. Emulsions of this embryo and its membranes in Hartley's broth were bacteriologically sterile, and when injected into eggs produced the picture which subsequently came to be regarded as characteristic for this virus, and has been uniformly reproduced in all succeeding experiments, in which more than 1500 eggs have been used. The characteristic appearance has so far persisted through more than thirteen serial passages.

Eggs usually received $\mathbf{0} \cdot 25 \mathrm{ml}$. of material. They were usually opened on the 4th or 5th day after inoculation, when affected eggs characteristically showed marked gelatinous oedema of the chorio-allantois, so that this membrane was often nearly $0.5 \mathrm{~cm}$. thick, semi-opaque and jelly-like in consistency. Welldefined focal lesions could not be distinguished, although large non-specific lesions were occasionally present along the larger blood vessels.

The amnion was often thickened and more opaque than normal, but wellmarked oedema like that in the chorio-allantois was seldom encountered. The amnion was usually tightly contracted round the undersized, shrivelled embryo. The embryo itself, apart from its small size, was tightly curled up and with little or no feather development. This feature varied a great deal according to the age of the embryo when infected.

Embryos more than 10 days old at the time of inoculation usually showed more feather development, especially along the back. The feathers were, however, poorly developed, the follicles and shafts irregularly swollen and often haemorrhagic. In younger eggs there was as a rule only slight follicle development limited to the back, and this part was frequently loosely adherent to the closely applied amnion. Numerous intracytoplasmic inclusion bodies were demonstrable in the skin and subcutaneous tissues. The histological features will be reported in detail elsewhere. The appearance of the featherless, shrunken, curled up embryo in its amnion was reminiscent more of an insect pupa enclosed within its pupal case than of a chicken (see Plate 1).

\section{The properties of the virus and attempts at its identification}

Filtration. Emulsions of whole embryo and membranes in Hartley's broth were, after preliminary clarification through paper-pulp, filtered in series through gradocol membranes with A.P.D.'s of 670, 270, 116 and $52 \mathrm{~m} \mu$. All filtrates were free of an indicator organism, Chromobacterium prodigiosum (Serratia marcesens), with which the original emulsion had been heavily seeded. Each filtrate was used for the inoculation of six 11-day-old eggs. They were observed for 4 days, after which all survivors were opened. (Limited supplies of eggs did not allow of titration of each filtrate.) The results recorded in Table 1 show that all filtrates contained the active agent.

There was some doubt at this stage whether the agent responsible for the abnormalities in the chick embryos could be regarded as a virus; that instead it might be a soluble toxic substance produced by a contaminating organism 
which would not grow in the ordinary bacteriological media in current use in the laboratory. In that event the agent would not be transmissible in series from eggs which in the first place had received a bacteria-free filtrate. Accordingly, one of the embryos (in Table 1) which showed specific lesions after inoculation with a $116 \mathrm{~m} \mu$ filtrate was used for further filtration, through membranes with A.P.D.'s of 270, 116, 52 and $21 \mathrm{~m} \mu$. That a filtrate through membranes of A.P.D. $52 \mathrm{~m} \mu$ or higher is still active is shown by the results

Table 1. Filtration of the virus through gradocol membranes

\begin{tabular}{|c|c|c|c|}
\hline \multicolumn{4}{|c|}{ A.P.D. of membranes $(\mathrm{m} \mu$.) } \\
\hline 670 & 270 & 116 & $\mathbf{5 2}$ \\
\hline Dธ Autolysed & D5 Autolysed & D5 Typical & D5 Autolysed \\
\hline D5 Autolysed & D5 Autolysed & D5 'Typical & D5 Autolysed \\
\hline D5 Typical & D5 Typical & K5 'Typical* & D5 Typical \\
\hline D5 Typical & D5 Typical & K5 Typical & K5 Typical \\
\hline K5 Typical & D5 Typical & K5 Typical & K5 Typical \\
\hline K5 Typical & K5 Typical & K5 Typical & K5 Typical \\
\hline
\end{tabular}

recorded in Table 2. The filtrate obtained through a membrane with A.P.D. of $21 \mathrm{~m} \mu$, on the other hand, completely withheld the virus. Although the exact determination of size requires further investigation, these results suggest that the particle size of the active agent lies between 10 and $25 \mathrm{~m} \mu$. Repetition of these experiments gave similar results.

Table 2. Filtration of the virus from embryo inoculated with a filtrate (cf. Table 1) through gradocol membranes

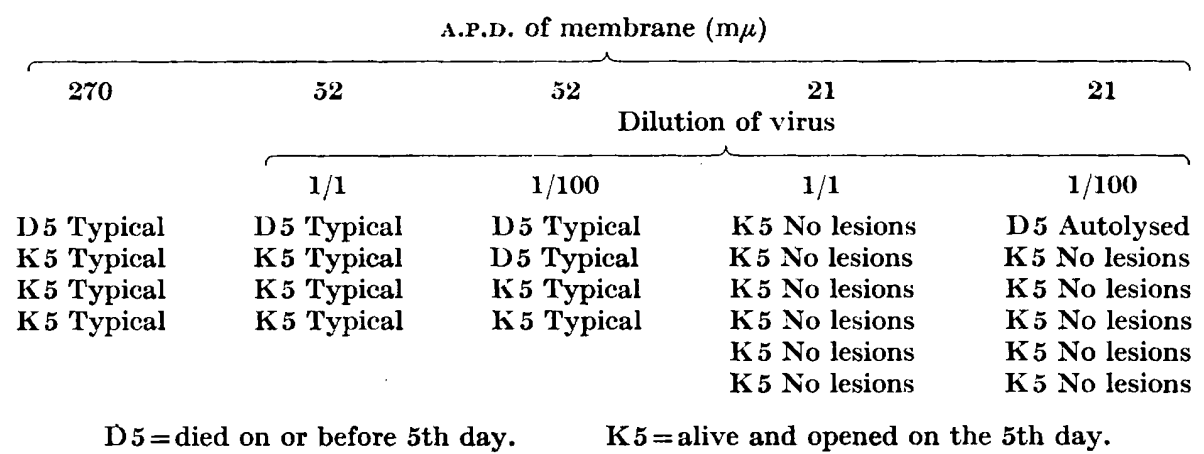

Titres of the virus in the chick embryo. Emulsions of whole embryo and membranes in a total volume of $15 \mathrm{ml}$. of mixed embryonic fluids and broth, centrifuged for $20 \mathrm{~min}$. at c. 3000 r.p.m., have been repeatedly titrated. Tenfold dilutions of the emulsion in Hartley's broth were each used to inoculate groups of three to six eggs. The results of a typical experiment are recorded in Table 3. 
Because non-specific deaths amongst the chick embryos were fairly frequent and irregular, reliance has not been placed on eggs which were dead at the time of opening (3rd, 4th or 5th day) unless autolytic changes were so slight that the lesions were unmistakable. Several times the results with higher dilutions were irregular, but even if that dilution giving rise to characteristic

Table 3. Result of titration of virus suspension in eggs

\begin{tabular}{|c|c|c|c|c|}
\hline \multicolumn{5}{|c|}{ Dilution of virus suspension } \\
\hline $10^{-2}$ & $10^{-5}$ & $10^{-5}$ & $10^{-6}$ & $10^{-7}$ \\
\hline $\begin{array}{l}2 \text { D4 Autolysed } \\
2 \text { K4 Typical } \\
-\end{array}$ & $\begin{array}{l}2 \text { D3 Autolysed } \\
2 \text { K4 Typical } \\
-\end{array}$ & 5K4 Typical & $\begin{array}{l}\text { 3D3 ?NS } \\
1 \mathrm{D} 4 \text { Autolysed } \\
1 \mathrm{~K} 4 \text { Typical }\end{array}$ & $6 \mathrm{K4}$ No lesions \\
\hline & $\begin{array}{r}\text { ?NS } \\
x \mathrm{D} y=x \mathrm{der} \\
x \mathbf{K} y=x \text { ali }\end{array}$ & $\begin{array}{l}\text { obably non-s } \\
\text { on or before th } \\
\text { and opened on }\end{array}$ & $\begin{array}{l}\text { ecific. } \\
\text { yth day. } \\
\text { he } y \text { th day. }\end{array}$ & \\
\hline
\end{tabular}

lesions in all the eggs inoculated, and which survive to the 4th day, be defined as the end-point, the titre must be accepted as fairly high: at least $10^{-5}$ of an emulsion consisting of one embryo in $15 \mathrm{ml}$. Subsequent titrations indicated an even higher virus content. Thus in neutralization tests reported below $10 \%$ suspensions $(w / v)$ of virus-infected embryos in broth were used. These suspensions on several occasions attained a titre of $10^{-8}$.

The effect of drying. Emulsions of whole embryo in allantoic fluid, centrifuged for 20 min. at c. 3000 r.p.m., were distributed in ampoules in $0.5 \mathrm{ml}$. amounts and then dried in a high-vacuum spin freeze-drier (Greaves, 1944), with and without preliminary freezing. The titre of reconstituted dry suspension has on each occasion been found to be approximately $10^{-2}$. There is therefore at least a thousandfold drop in titre on drying by this method, but once dry the material maintained its potency with little or no alteration for several months.

Table 4. Susceptibility of the virus to heat

\begin{tabular}{|c|c|c|}
\hline \multicolumn{3}{|c|}{ 'Treatment } \\
\hline Unheated & $60^{\circ}$ for $20 \mathrm{~min}$. & $100^{\circ}$ for $2 \mathrm{~min}$. \\
\hline $1 \mathrm{D4}$ Typical & 11) 4 Autolysed & $4 \mathrm{K4}$ No lesions \\
\hline 4K4 Typical & 2K4 Typical & - \\
\hline 1 K4. Typical (slight) & 1 K4 Typical (slight) & - \\
\hline
\end{tabular}

Susceptibility of the virus to heat. Samples of undiluted emulsions of virusinfected embryo were heated to $60^{\circ}$ for $20 \mathrm{~min}$. or to $100^{\circ}$ for $2 \mathrm{~min}$. The heated emulsion, as well as control material which had been left at room temperature, was inoculated into 10-day-old chick embryos. The results recorded in Table 4 show that this virus can withstand heating to $60^{\circ}$ for 20 min., but that boiling destroys it. In one experiment it was found to be destroyed by overnight incubation at $37^{\circ}$. The virus maintained its infectivity for the eggs at refrigerator 
temperatures $\left(+4^{\circ}\right)$ for at least a month, and its potency for at least a week in $50 \%$ glycerol at $+4^{\circ}$.

Pathogenicity for chicks and adult fowls and preparation of immune serum. Adult fowls and day-old chicks were obtained from the supplier of the fertile eggs used in this investigation. Fresh chick embryo emulsion was injected intramuscularly and subcutaneously into four adult fowls and four 1-day-old chicks. At the same time some of the inoculum was rubbed into the skin of a small area on the chest from which the down or feathers had been plucked. None of the birds developed any symptoms or signs of illness during a 3 weeks' observation period.

Table 5. Neutralization of virus by immune fowl serum, and by normal and convalescent bovine sera

\begin{tabular}{|c|c|c|c|c|c|}
\hline & \multicolumn{5}{|c|}{ Inoculum } \\
\hline & Virus + broth & $\begin{array}{l}\text { Virus + normal } \\
\text { fowl serum }\end{array}$ & $\begin{array}{l}\text { Virus }+ \text { immune } \\
\text { fowl serum }\end{array}$ & $\begin{array}{l}\text { Virus +'normal' } \\
\text { bovine serum } \\
\text { (local) }\end{array}$ & $\begin{array}{l}\text { Virus + con- } \\
\text { valescent bovine } \\
\text { serum }(6440)\end{array}$ \\
\hline $\mathbf{A}$ & $\begin{array}{l}\text { 2I4 Autolysed } \\
\text { 3K4 Typical }\end{array}$ & $\begin{array}{l}\text { 1 D4 Autolysed } \\
1 \text { K4 No lesions* } \\
\text { 3 K4 Typical }\end{array}$ & $\begin{array}{l}1 \mathrm{D} 4 \text { Autolysed } \\
\text { 3K4 No lesions }\end{array}$ & $\overline{-}$ & $\begin{array}{l}\text { 2D4 Autolysed } \\
2 \text { K4 No lesions }\end{array}$ \\
\hline B & $\begin{array}{l}\text { 2D4 Autolysed } \\
4 \text { K4 Typical }\end{array}$ & - & - & $\begin{array}{l}\text { 2D4 Autolysed } \\
1 \mathrm{~K} 4 \text { Typical }\end{array}$ & $\begin{array}{l}2 \mathrm{D} 4 \text { Autolysed } \\
\text { 1 K4 Slight } \\
\text { lesions }\end{array}$ \\
\hline & $\begin{array}{c}1 \mathrm{~K} 4 \text { Typical } \\
\text { (slight) } \\
-\end{array}$ & - & - & $\begin{array}{l}\text { 3 K4 Slight } \\
\text { lesions } \\
1 \text { K4 No lesions }\end{array}$ & $4 \mathrm{~K} 4$ No lesions \\
\hline
\end{tabular}

* The absence of lesions in one egg while others of the same group showed typical lesions, was seen very occasionally even using inocula of many infective doses. The explanation is that occasionally the inoculum is accidentally placed outside the amniotic cavity, in spite of precautions taken to avoid this.

$x \mathrm{D} y=x$ dead on or before the $y$ th day.

$x \mathrm{~K} y=x$ alive and opened on the $y$ th day.

The adult fowls then received six further injections at 2- or 3-day intervals, each of one-quarter of a virus-infected embryo and membranes emulsified in saline. They were bled from a wing vein on the 10th day after the last injection, and the Seitz-filtered serum was stored in measured amounts in the dry state.

\section{Neutralization tests with the sera of fowls immunized against the egg virus and of bovines convalescent from Lumpy Skin Disease}

In the earlier part of this work dry stock virus of known titre was used. The dry stock virus with a titre of $10^{-2}$ was reconstituted in broth. Appropriate dilutions were mixed with equal volumes of various serum samples under test. In the controls broth was used instead of serum. The results of a typical experiment are recorded in Table 5 .

These results were obtained with relatively small numbers of eggs, but similar findings were obtained in other experiments. Table 5 shows, in addition, 
that 'normal' bovine serum obtained from a local slaughterhouse possessed neutralizing power, though less than that of known convalescent sera. A study of the incidence of the disease in dairy herds revealed that often the majority of animals in a herd are refractory to the disease. This may be because these animals have suffered an inapparent infection at the time of the outbreak or previously. As the slaughterhouse was supplied from areas in which the disease was at the time prevalent, the serum obtained from them could not be regarded as providing satisfactory normal controls.

Sera were subsequently obtained from bovines which had at no time been exposed to the risk of infection, and from animals which had suffered the disease under controlled experimental conditions. These sera were tested according to the method here described, as well as by a second method using fresh virus suspensions instead of dried virus. The modification in technique was introduced because of the possible interference with the neutralizing power of serum by a large amount of inactivated virus present in dried suspensions. With one exception the results of these further experiments confirmed the presence of neutralizing antibody in the sera of cattle convalescent from the disease, and the absence of antibodies from the sera of normal cattle. These experiments, which were undertaken together with Dr R. Alexander of Onderstepoort, will be reported in detail elsewhere.

\section{The control serial passage of normal chick embryo material}

Throughout the preliminary work it was realized that the virus which had been isolated might bear no relation to the etiology of Lumpy Skin Disease in cattle. One of the possibilities, though extremely remote, was that serial transfer may have revealed a latent virus present in the eggs. Beveridge $\&$ Burnet (1946) point out that the usefulness of eggs in virus research depends to a large extent on the fact that no latent viruses have yet been demonstrated in eggs.

It was decided, nevertheless, to carry out a parallel series of egg passages with normal embryo as starting material. An attempt was made to carry out these passages and the virus transfer under identical conditions. Often, therefore, the virus and control passages were done at the same bench, on the same morning, and using the same instruments. It was also not realized at this time that the virus was relatively heat-resistant. Risks of accidental transfer of the virus to the control normal embryo passage series were therefore great, and this was brought out by subsequent experience. Characteristic virus lesions suddenly appeared in the control series after three passages.

A fresh series of controls was therefore started and carried out with every precaution to prevent contamination. This series was abandoned after the 10th serial transfer, without the occurrence of any lesions resembling those due to virus. Subsequently serial passages in eggs have been undertaken on numerous occasions without the appearance of lesions resembling those described above. 


\section{DISCUSSION}

There can be little doubt that the agent isolated in eggs is a virus. It produces characteristic lesions even when given in small doses, multiplies actively in the eggs, is filtrable, and is antigenic. Its size according to the preliminary experiments recorded in this paper is in the region of $10-25 \mathrm{~m} \mu$.

It seems probable that the occasional occurrence of gelatinous chorioallantoic membranes and abnormalities of the embryo recorded with the first series (L) was due to the same agent. That these findings were not more frequent can probably be explained by the fact that older embryos were used for those experiments. Subsequent experience has shown that embryos are much less susceptible when infected after skin and feather development is well advanced. Also in series L attention was paid particularly to the lesions on the chorio-allantois for which the older eggs appeared at the time to be more satisfactory. Later experience with series $W$ indicates that although virus multiplies in the chorio-allantois, it produces no constant recognizable abnormality of the membranes or embryo, apart from the somewhat irregular development of a striking gelatinous oedema of the chorio-allantois.

The exact nature of the virus cannot be established until pathogenicity tests have been carried out in a variety of animals, including bovines. The neutralization of virus by sera from animals convalescent from Lumpy Skin Disease is, however, presumptive evidence that the virus may be etiologically related to the bovine disease. It is interesting in this connexion that the apparent size of the virus is nearer that of foot and mouth disease than that of the animal pox viruses.

It is striking that isolation of the virus succeeded only on one occasion; in an earlier attempt the virus lesions were probably present, though they were unrecognized. In spite of repeated efforts, every subsequent attempt to isolate the virus has failed. It may be significant that the successful material was obtained from a fatal case in a calf during the earlier phases of the epidemic, whereas subsequent material was obtained by biopsy from adult animals, all of which recovered.

We are grateful to Dr M. Horwitz for help in collecting material; to Dr Bull, Mr H. Woods, Mr Louw, Mr H. Levinkind, Mrs Machanick and others who gave us access to material on their farms. Dr G. Selzer kindly examined the histological preparations for us, Mr W. Taylor prepared the photograph, and Mr G. S. Turner gave us valuable assistance in the laboratory. The constant helpful interest of Dr R. Alexander was a great encouragement to us.

\section{REFERENCES}

Beveridge, W. I. B. \& Burnet, F. M. (1946). The cultivation of viruses and rickettsiae in the chick embryo. Spec. Rep. Ser. med. Res. Coun., Lond., no. 256. London: H. M. Sta. Office.

DE Boom, H. P. A. (1947). Knopvelsiekte: 'n Kort oorsig. S. Afr. Sci. 1, 44.

Greaves, R. I. N. (1944). Centrifugal vacuum freezing. Its application to the drying of biological materials from the frozen state. Nature, Lond., 153, 485. 

Journal of General Microbiology, Vol. 3, No. 2

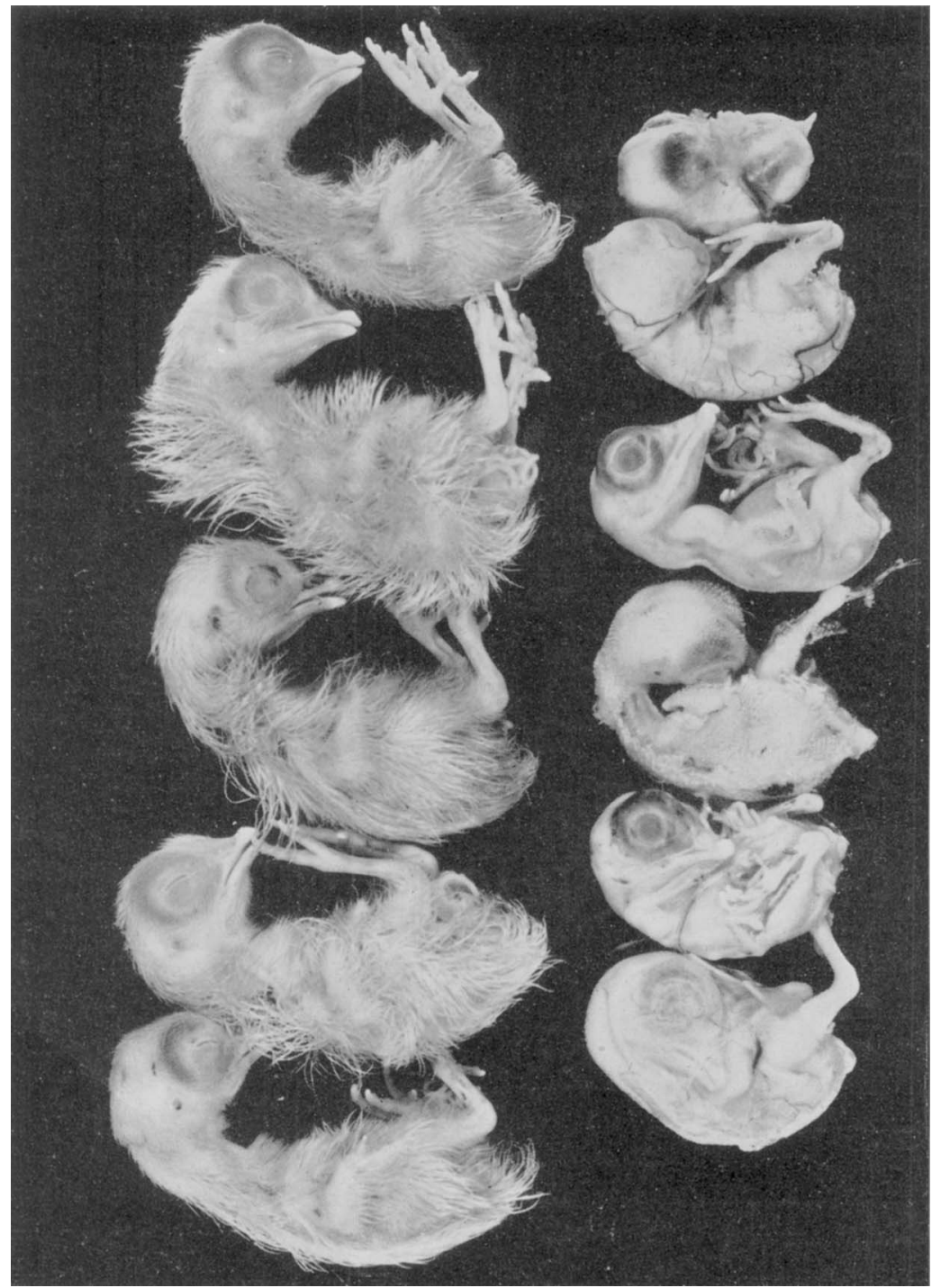

Normal

With virus

M. van den finde, Puylis A. Don and A. Kipps-'The agint of Bovine Lumpy Sirin Diskase. Plate 1 
MacDonald, R. A. S. (1931). Pseudo-urticaria of cattle. Dep. Anim. Health, Govt. Northern Rhodesia, Ann. Rep. 1930, p. 20.

Morris, J. P. A. (1931). Quoted by de Boom (1947).

Thomas, A. D. \& Mare, C. v. E. (1945). Knopvelsiekte. J.S.A. vet. med. Ass. 16, 36. von Backstrom, U. (1945). Ngamiland cattle disease. Preliminary report on a new disease, the etiological agent being probably of an infectious nature. J.S.A. vet. med. Ass. 16, 29.

\section{EXPLANATION OF PLATE}

The five embryos at the right show the typical lesions caused by the filterable agent. The five embryos at the left are normal, and of the same age.

(Received 5 July 1948) 